\section{Making a difference}

\section{Do Animals Think?}

by Clive D. L. Wynne

Princeton University Press: 2004. 288 pp. $\$ 26.95, \mathfrak{1} 17.95$

\section{Sara J. Shettleworth}

Dogs that learn words the way a child does and crows that make tools catch our interest because their behaviour seems so unexpectedly human-like. Many books on animal mind and behaviour for general readers feed an appetite for seeing animals as being like us, either by detailing the way experiments reveal animals' abilities to count, form concepts and so on, or by describing the behaviour of some particular animals, often primates. Donald Griffin's Animal Thinking (Harvard University Press, 1984) or Marc Hauser's Wild Minds (Henry Holt, 2000) come to mind as examples of the first genre, and books by Frans de Waal, such as The Ape and the Sushi Master (Basic Books, 2001), are examples of the second.

Do Animals Think? most resembles books of the first genre, but with a difference. In this critical account of selected research, Clive Wynne takes aim at over-sentimental anthropomorphism, particularly on the part of animal-rights advocates. He argues that the degree to which animals are like us cannot be the measure of how much they are worthy of our respect and protection. To take one of Wynne's examples, it is fine to take pleasure from watching dolphins leap simply because they look so joyful, but it is important to know the facts about dolphin behaviour and to realize that - contrary to what some sources quoted in the book would have you believe - they have neither self-awareness nor a complex language, nor perhaps take joy in leaping. How can a concern for animals exist alongside an objective understanding that their minds and behaviour are in many respects very unlike ours?

To capture his theme that animals are like us in some ways but not in others, Wynne adopts the not entirely successful simile of a sandwich with two layers of difference

\section{Reissued classics}

The Cosmic Blueprint: New Discoveries in Nature's Creative Ability to Order the Universe

by Paul Davies

Templeton Foundation Press, $\$ 16.95$

A return to print for this 1988 classic.

\section{Ben Franklin Stilled The Waves}

by Charles Tanford

Oxford University Press, £9.99, \$16.95

A charming historical voyage, ending in the discovery of the lipid bilayer surrounding cells.

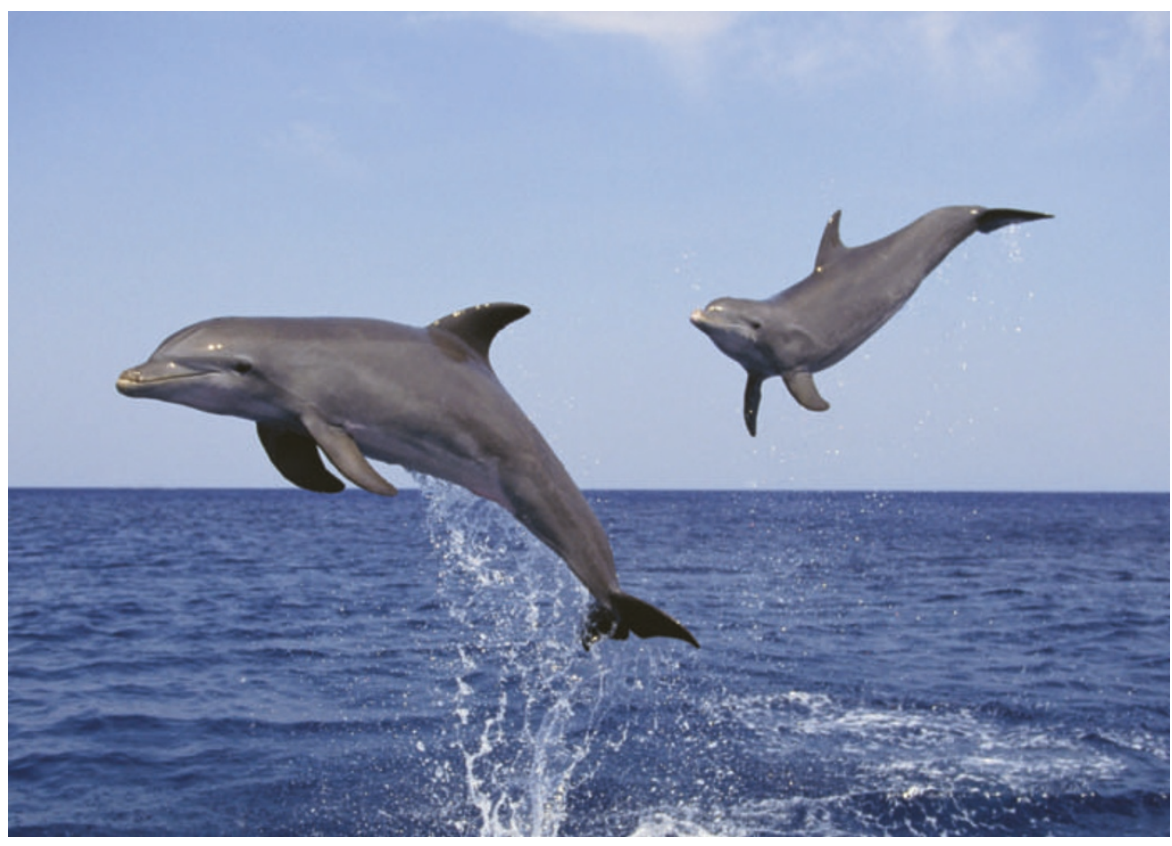

Jumping for joy? The sight of dolphins leaping out of the water can tempt us to be anthropomorphic.

surrounding a layer of similarity. The outer layers are species-specific sensory systems and abilities such as the echolocation of bats, the still mysterious homing of pigeons, and the linguistic abilities of humans. The filling is cross-species similarity in basic instincts and simple learning abilities.

The book is structured like a sandwich, too. Chapters on humans' attitudes to animals and how they can be justified surround a seven-layered 'filling' made up of chapters devoted to the animals themselves, with the sensory, communicative and social systems of honeybees, bats, pigeons and dolphins alternating with chapters on contemporary research into animal minds. This juxtaposition of psychological topics, such as tests of reasoning (from Wolfgang Kohler onwards), tool use, imitation, ape language, mirror selfrecognition and theory of mind, together with accounts of the behaviour and life histories of bats, dolphins and bees, is an effective device for underlining the 'otherness' of animal lives and minds.

All this material is presented in a clear, informal and entertaining way, enlivened by historical asides, among which I most enjoyed the speculations on why Kohler was studying chimpanzees on Tenerife in the first place and the passages from an Elizabethan bee-keeping manual. But, at risk of overstraining the comparison, this sandwich contains some substantial chunks of meat that some readers will have trouble swallowing. Wynne emphasizes that misconceptions by non-specialists and overly anthropomorphic interpretations by researchers are rife in areas where animals' behaviour seems most to resemble human behaviour. Moreover, the degree of resemblance between animal and human behaviour is too easily exaggerated, he says. For instance, population-specific forms of tool use and other learned behaviours in chimpanzees are rightly seen as a form of culture, but it should not be forgotten that even an hour's observation of any group of humans would reveal vastly more complex culturally transmitted behaviours.

Many comparative psychologists who, like Wynne, do experimental research with animals will probably applaud his critical approach to such topics as theory of mind and animal language, and will not find his conclusions controversial. But the final provocative chapter, on why we should care about animals, is unsatisfactory. Wynne rejects first, and in some detail, the idea that animals should have rights. His specific dismissal of the Great Ape Project, which believes that great apes should enjoy the same rights as humans, will raise some hackles. The absence of sound evidence that even chimpanzees have the cognitive capacity for legal responsibility makes the animal-rights position, in his view, as untenable as that of the sixteenth-century villagers who tried rats for eating their crops. The utilitarian view that the recognition of animals' capacity for suffering gives us a guide fares little better, primarily because, Wynne argues, a calculus of suffering is ultimately impossible to apply in detail.

What we're left with, after what is hardly a complete survey of contemporary views, is that it is simply self-evident that we should value and protect animals whether or not they are in any way like us. Perhaps others will take up the challenge of developing a coherent account of how concern for animals is consistent with a dispassionate view of their minds and behaviour.

Sara J. Shettleworth is in the Departments of Psychology and Zoology, University of Toronto, Toronto, Ontario M5S 3G3, Canada. 